\title{
Sero-Epidemiological Investigation on Peste Des Petits Ruminants in Black Bengal Goats
}

\author{
Kamol Kishire Das ${ }^{1}$, Niraj Kanti Shil ${ }^{2}$ and M Rafiqul Islam ${ }^{3 *}$ \\ ${ }^{1}$ Department of Microbiology \& Hygiene, Bangladesh Agricultural University (BAU), Mymensingh 2202, Bangladesh, ${ }^{2}$ Department of Medicine, \\ Bangladesh Agricultural University (BAU), Mymensingh 2202, Bangladesh, ${ }^{3}$ Bangladesh Livestock Research Institute, Savar, Dhaka 1344, \\ Bangladesh
}

[Received 04 December 2007; Accepted 08 December 2007]

\begin{abstract}
A natural outbreak suspecting PPR (peste des petits ruminants) was thoroughly investigated and confirmed by monoclonal antibody (mAb)-based enzyme immuno slide assay (EISA). Nasal discharge in early stage of disease course, diarrhoeic faeces and lung as a post-mortem sample was a source of sufficient virus to be detected by this technique. Convalescent polyclonal sera from the recovered animal diagnosed as PPR by EISA revealed high antibody titre by competitive-ELISA. It was found that EISA is suitable, sensitive and specific to confirm PPR infection in both field and laboratory conditions especially in developing country. In the affected houses morbidity and mortality rate was $\mathbf{7 4 . 1 3 \%}$ and $54.83 \%$ respectively and observed high in the age group of 5-8 weeks, but sex difference was not significant. Early rainy season (July 2006) was the period of the present outbreak. Sero-positive animal closer to the outbreak area concluded that virus was circulating in the experimental area of Mymensingh district. Vaccinated sero-nagative animal could withstand the natural disease onset. Purchase of new animal from market and grazing in the same field with infected goats was the source of present outbreak.
\end{abstract}

\section{Introduction}

Clinically, peste des petits ruminants (PPR) is characterized by erosive stomatitis, enteritis with diarrohea and pneumonia. The outbreaks of a rinderpest like disease later confirmed by World Reference Laboratory to be PPR have been occurring in goats since 1993 in Bangladesh and found that the virus has a close relation with the Indian isolates (West Bengal) of PPRV at a cluster with Asian group ${ }^{1}$. The overall sero-prevalence was 36.00 , 49.17 and $19.05 \%$ in sheep, goat and cattle respectively in Bangladesh $^{2}$. Prevalence is higher in indigenous Black Bengal goats than exotic breed like Jamunapari ${ }^{3}$. Immunosuppression is commonly found in morbillivirus infection and this is thought to contribute susceptibility to secondary infections that accounts for most of the mortality due to PPR infection ${ }^{4}$. A monoclonal antibody based enzyme immuno slide assay (EISA) has been developed on glass slide for the rapid and accurate detection of PPR virus from excretion and pathological homogenized tissue sample of infected animals ${ }^{5}$. In this paper a suspected PPR outbreak was studied using EISA technique to further check the suitability of the method using field samples and later confirmed by Competitive ELISA. The epidemiological factors related to disease outbreak were thoroughly investigated to set up a possible control strategy.

\section{Materials and Methods \\ Study population}

The study was carried out in six houses in a village (Napterali) at Mymensingh district with a natural field outbreak suspected to be peste des petits ruminants (PPR) in goats. Apparently healthy goats $(n=38)$ without vaccination history were also investigated in nearby houses with a distance of 0.5 to 1 kilometres.

\section{Clinical study}

The disease courses of the infected animal were observed and recorded. Investigation of clinical signs and symptoms was concluded primarily as PPR. Among the studied population, 23 goats were found to be infected and later 17 goats died.

\section{Test sample}

Nasal and oral swabs were taken on cotton swabs at 4-6 days of the disease onset. Faecal swabs were collected after onset of diarrhoea. Necropsy examination of dead goats was performed and lung, spleen, lymph nodes and intestines were collected aseptically and kept at $-80^{\circ} \mathrm{C}$. Polyclonal test sera of six convalescent goats and healthy goats were collected and stored at $-20^{\circ} \mathrm{C}$ until further use.

\section{EISA technique}

Reference PPR virus as antigen and monoclonal antibodies used for the study were obtained from C-ELISA kit (IAEA and BDSL, 
UK). EISA test was conducted in samples coated glass slides or in 12 wells glass plates after acetone fixation ${ }^{5}$. Smears were prepared using nasal, oral discharges and diarrhoeic faeces. Cotton swabbing of the infected tissue samples (lung, spleen, lymph nodes and intestines) were performed aseptically before smearing on slide or plate. The smear was air dried and fixed in ice cold acetone for $15 \mathrm{~min}$, used immediately or kept at $4^{\circ} \mathrm{C}$ for further use. In brief, monoclonal antibodies against PPR virus (1:100 in PBS) was added at an amount of $50 \mu \mathrm{l} /$ smear/well, while plate or negative control was kept using $50 \mu \mathrm{l} /$ well blocking buffer solution. For every assay the PPR antigens (reference) were kept as positive control. Slide/plates were incubated at $37^{\circ} \mathrm{C}$ for an hour and wash with PBS (1:5) and air dried. After drying, $50 \mu \mathrm{l}$ of anti-mouse IgG conjugate (1:1000 in buffer solution) was added to all wells. The slide was then incubated at $37^{\circ} \mathrm{C}$ for $1 \mathrm{~h}$. Fifty microlitre of ortho-phenylendiamine (Sigma, UK) mixed with hydrogen peroxide $(1: 200)$ was added to each well and incubated for $15 \mathrm{~min}$ at room temperature. The reaction was stopped by the addition of $50 \mu \mathrm{l}$ of sulphuric acid (6.8\%) and examined by naked eyes (golden yellow colour change in positive cases) or optical densities of the samples were measured at $492 \mathrm{~nm}$ with a computerized ELISA reader.

\section{Competitive-ELISA}

Sera collected from the convalescent animals after field outbreaks from PPR infection (antigen detected by Mab-based EISA) were tested for the presence of PPR specific antibody to confirm results obtained by EISA using Mab-based competitive ELISA as per technique described elsewhere ${ }^{6}$. Serum antibody titres of apparently healthy goats before and after vaccination were also measured.

\section{Vaccination}

Vaccination of the sero-negative goats from the nearby houses was performed. Live attenuated PPR vaccine produced in Livestock Research Institute (LRI) Mohakhali, Dhaka was used for this study. The vaccine was given subcutaneously in the cervical region at the dose rate of $1 \mathrm{ml}$ per animal. Vaccinated animals were observed for any natural disease outbreak.

\section{Results}

\section{Clinical and post mortem findings of PPR suspected goats}

Fever, dry muzzle, anorexia followed by serous to mucopurulent nasal discharge, severe stomatitis with necrotic lesions in the buccal cavity, diarrhoea and respiratory distress were recorded as the main clinical signs. Dyspnoea with cough, frothy salivation, conjunctivitis, depression etc. were also manifested. Abrupt rise of body temperature $\left(103-107^{\circ} \mathrm{F}\right)$, which is the most striking feature of PPR infection and the temperature rising was occurred from first day of infection.

Four dead goats revealed severely dehydrated and emaciated carcasses following post-mortem examinations. Haemorrhages on the mucosa of the jejunum, ileum and colon and the pathognomonic lesion 'Zebra stripe' were observed in caecocolic junction in all goats. Spleen of goats was atrophied and lymph nodes were found enlarged. There were eroded and ulcerated mouths and the tracheas were congested along with frothy mass in the lumen of tracheas. Lungs showed congestion and consolidation. The morbidity and mortality was recorded $74 \%$ and 55\% respectively in the present study.

\section{PPRV detection from discharges and post-mortem sample}

High level of PPR antigen was detected from nasal discharges ranging from 0.449 to 0.945 . The average OD values of nasal, oral and faecal discharge were $0.77 \pm 0.13,0.27 \pm 0.04$ and $0.62 \pm 0.11$ respectively. Optical density values varied from 0.307 to 0.892 for different postmortem tissue sample. There was found that PPRV concentration was higher in lung $(0.85 \pm 0.06)$ compared to intestine $(0.75 \pm 0.04)$, lymph nodes $(0.62 \pm 0.08)$ and spleen $(0.46 \pm 0.15)$. The optical density (OD) values less than or equal to 0.097 were considered as negative.

Serological status of PPR antibodies in recovered goats, apparently healthy goats and determination of antibody responses to PPR vaccine

Convalescent sera of the recovered animal after a field outbreak were tested by C-ELISA against PPR antigen and found high level of PPR specific antibody (average percent of inhibition [PI] was $81.99 \pm 3.82$ ). During outbreak of PPR the sera were collected from 38 goats from the houses with a distance of 0.5 to 1.0 kilometre of the affected houses. The mean antibody titres of sera were $29.95 \pm 12.14$ and $56.45 \pm 5.02$ in case of sero-negative (PI value $<50 \%$ ) and sero-positive (PI value $\geq 50 \%$ ) goats respectively. Percent of sero-positive goats was 60.53 and in case of seronegative 39.47. After vaccination of sero-negative goats, average antibody titres were $62.6 \pm 5.61$ at $14^{\text {th }}$ day and $73.25 \pm 3.23$ at $28^{\text {th }}$ day post vaccination.

\section{Discussion}

A naturally occurring peste des petits ruminants (PPR) of goats was investigated. Clinical signs and postmortem features were considered for primary clinical diagnosis of PPR. In this study smear was prepared by discharges, faeces and swabbing of crude tissue sample from suspected field outbreak showed that EISA was able to detect PPR antigen from nasal and oral discharge, faecal sample and postmortem tissues. This test is rapid, economic and can be performed at field condition, keeping sample at ambient temperature for one week (data not shown). These results have later been confirmed by C-ELISA using convalescent sera against PPR antigen. The high level of PPR specific antibody of recovered animal supports the specificity of EISA as one of the major diagnostic tools for epidemiological investigation of PPR infection. Thus after the disease course the animal posses a durable immunity and remain resistant to subsequent infection ${ }^{7}$. The clinical signs and symptoms observed in the present outbreak were similar to those reports in case of PPR of goats from different geographical areas $^{3,8-11}$. 
In the early stage of disease course, nasal discharge showed higher level of viral antigen than oral discharge and faecal sample considered as a suitable virus antigen source for diagnosis after onset of diarrhoea. Similar results were obtained using Immuno Capture ELISA (ICE) ${ }^{12}$ and EISA ${ }^{5}$. Nasal discharge sampling seemed to be less traumatic and remain as a good source of antigen until mucopurulent. Smear prepared from lung samples revealed more deep golden brown colour change in EISA test. Less quantities of virus antigen was detected in spleen than intestine and lymphnodes confirming result previously obtained elsewhere ${ }^{13}$.

The morbidity and mortality rate was 74 and 55\% respectively. Age group 5-8 weeks was found highly susceptible and mortality also observed more. The results were in agreement with the results obtained by others researcher ${ }^{7,14-16}$. The Morbidity and mortality of male goats were more but this sex difference was not significant due to less population studied ${ }^{11}$. The present outbreak of PPR in Napterali village was occurred in July, 2006 (rainy season) ${ }^{7}$. At the time of disease outbreak, the mean of PPR sero-positive antibody titre of apparently healthy goats from nearby house was $56.45 \pm$ 5.02. It could be concluded that virus was circulating in the experimental area of Mymensingh district ${ }^{5,17}$. Vaccination of the sero-negative goats from the neighbour's houses was performed with live attenuated PPR vaccine. No disease of vaccinated animals was observed subsequently. Thus vaccination could protect the susceptible animal nearer to an outbreak.

There was a history of PPR outbreak in the neighbouring village Batipara and Khasiarchar before and after the studied area respectively. It was also found from the interview of the farmers that the goats of a certain area generally grazed in one or two common grass field. Farmers are not well concerned about the pitfall of mixing sick and healthy animal for grazing. In case of village practice it is found that diseased goats and in contact goats usually sold to the market if any outbreak occurred. Before this outbreak a no of goats were also procured from local market and mixed with home stock. The purchase of new stock from market and the return of unsold animals often precipitated severe outbreaks ${ }^{18,19}$. So awareness program should be taken targeting smallholder goat and sheep farmers regarding large scale vaccination against PPR in a certain area, proper quarantine after purchasing new animals from village market, separation of sick animals and proper hygienic measure in the house of affected flock along with full course treatment to combat the secondary infection. In the livestock market of urban and semi-urban area saleable animal also should be checked with trained personnel before mixing with healthy stocks.

\section{References}

1. Barrett T, Pronab D, Sreenivasa BP \& Corteyn M. 1997. Recent epidemiology of peste des petits ruminants virus. Vet Microbiol. 88(2): 125-130.

2. Rahman MB, Razzaque MA, Kafi MA \& Islam MR. 2005. Seroprevalence of PPRV specific antibodies in sheep, goat and cattle in different villages of Mymensingh. Presented to the $21^{\text {st }}$ Annual Conference of Bangladesh Society of Microbiologist, Mymensingh,
Bangladesh, $1^{\text {st }} 2^{\text {nd }}$ July 2005. Bangladesh Society of Microbiologist, Dhaka, Bangladesh.

3. Mondal AK, Chottopadhay AP, Sarkar SD, Saha GR \& Bhowmik MK. 1995. Report on epizootological and clinico-pathological observationon peste des petits ruminants(PPR) in West Bengal. Ind $J$ Anim Health Bull. 64: 261.

4. Haeney J, Barrett T \& Cosby SL. 2002. Inhibition of in vitro Leukocyte proliferation by morbilliviruses. J Virol. 76: 3537-3584.

5. Sil BK, Taimur MJFA, Hossain KM, Giasuddin M, Haque ME, Rahman MM, Roy A, Alam J, Islam MR, Rasid B, Akter N, Pramanic BK \& Anower AKMM. 2001. Development of Mab-based enzyme immuno slide assay (EISA) for the rapid detection and accurate field diagnosis of peste des petits ruminants virus. Bangladesh J Lives Res. 7: 48-63.

6. Anderson J. 1990. The use of monoclonal antibodies in competitive ELISA for the detection of antibodies to rinderpest and peste des petits ruminants viruses; the sero-monitoring of rinderpest throughout Africa. Phase one. Paper presented to the Final Research Co-ordination Meeting of the FAO-IAEA-SIDA-OAU-IBAR-PARC Co-ordinated Research Programme, Bingerbille, Cote d'Ivoire, $19^{\text {th }}-23^{\text {rd }}$ November 1990, pp 45-53. IAEA-TECHDOC, 623. Bingerbille, Cote d'Ivoire.

7. Sil BK, Rahman MM, Taimur MJFA \& Sarker AJ. 1995. Observation of outbreaks of PPR in organized goat farms and its control strategy. Presented to the Annual. Congress of the Bangladesh Society of Veterinary Education and Research, BARC, Dhaka, $3^{\text {rd }}$ December 1995. Bangladesh Society of Veterinary Education and Research, Dhaka, Bangladesh.

8. Debasis J, Mousumi G, Jana D \& Ghosh M. 2002. Incidence of an explosive outbreak of peste des petits ruminants (PPR) in Black Bengal goats in Bankura District of West Bengal. Ind Vet J. 79: 739740 .

9. Kumar A, Singh SV, Rana R, Vaid RK, Misri J \& Vihan VS. 2001. PPR outbreaks in goats; epidemiological and therapeutic studies. Ind $J$ Anim Sci. 71: 815-818.

10. Pawaiya RVS, Misri N, Bhagwan PSK \& Dubay SC. 2004. Pathology and distribution of antigen in goats naturally infected with peste des petits ruminants virus. Ind J Anim Sci. 74: 35-40.

11. Shankar H, Gupta VK \& Singh N. 1998. Occurrence of peste des petits ruminats like disease in small ruminants in Uttar Pradesh. Indian J Anim Sci. 68: 38-40.

12. Libeau G, Diallo A, Colas F \& Gueree L. 1994. Rapid differential diagnosis of Rinderpest and PPR using an immunocapture ELISA. Vet Record. 134(12): 300-304.

13. Wamwayi HM, Rossiter PB \& Wafala JS. 1991. Confirmation of riderpest in experimentally and naturally infected cattle using microtitre techniques. Trop Anim Health Pro. 23(1): 17-21.

14. Dhar P, Sreenivasa BP, Barrett T, Corteyn M, Singh RP \& Bandhyay SK. 2002. Recent epidemiology of PPRV. Vet Microbiol. 88: 1531590 .

15. Obi T, Ojo MO, Durajaiye OA, Kasali OB, Akparro S \& Opasina BA. 1993. The production of PPR hyperimmune sera in rabbits and their application in virus diagnosis. Zentlb Vet Med Sci. 30: 751.

16. Opasina BA \& Putt SNH. 1985. Outbreaks of PPR in village goat flocks in Nigeria. Trop Anim Health Pro. 17(4): 219-224.

17. Lefevre PC, Diallo A, Schenkel F, Hassein S \& Staak G. 1991. Serological evidence of PPR in Jordan. Vet Record. 128: 110-111.

18. Asmer JA, Radwan Al, Abi Assi E \& Rasheid A. 1980. PPR outbreaks in goats and sheep. Presented to the Annual Meeting of Saudi Arabian Association of Biological Science, Saudi Arabia, 1980, 37(2). Saudi Arabian Association of Biological Science, Saudi Arabian.

19. Bonniwell MA. 1980. Occurrence of PPR in sheep and goats. Bull Office Int Epizootics. 92: 1233-1235. 